\title{
Efficacy of some synthetic antibiotics on Streptococcus pneumoniae and Proteus mirabilis isolated from fish tanks
}

Idowu*, A.A., Ikenweiwe, N. B. Alimi, A. A and Akinyemi, A.A.

Department of Aquaculture and Fisheries Management, Federal University of

Agriculture, Abeokuta, Ogun state, Nigeria

*E mail: idowudoyin@yahoo.com

\begin{abstract}
Effects of some synthetic antibiotics on Streptococcus pnemoniae and Proteus mirabilis isolated from cultured Clarias gariepinus, an important food fish raised in a concrete tank was carried out to ascertain their remedies on mortalities of the Clarias gariepinus adult fish. Streptococcus pnemoniae and Proteus mirabilis were isolated from the gill and skin of diseased fish and water samples and identified by standard microbiological methods. The bacteria isolates were tested for sensitivity on ten (10) antibiotics namely Amoxycillin, Gentamicin, Nitrofurantoin, Erythromycine, Augmentin, Tetracycline, Naladoxic acid, Cotrimoxazole, Cloxacillin and Ofloxacin. These organisms reacted differently to the different antibiotics that were used - Ofloxacine, Gentamycin and Erythromycine had highest zones of inhibition of $26 \mathrm{~mm}$ and $26 \mathrm{~mm}, 24 \mathrm{~mm}$ and $19 \mathrm{~mm}, 16 \mathrm{~mm}$ and $17 \mathrm{~mm}$ respectively around Streptococcus pnemoniae and Proteus mirabilis, but Naladoxic acid, Augmentin, Cloxacillin and Amoxycillin had no inhibition zones around both organisms. It is therefore recommended that Ofloxacine, Gentamycin and Erythromycine can be used to combat S. pnemoniae and P. mirabilis diseases in fish farms because of their high antibacterial potentials against the test organisms.
\end{abstract}

Keywords: Streptococcus pnemoniae, Proteus mirabilis, Clarias gariepinus, Synthetic antibiotics

\section{Introduction}

Fish diseases are one of the major problems on fish farms. Intensification of fish farming in Nigeria has increased the number of disease outbreaks in intensive production systems. Most etiological agents were not yet identified and their morbid processes still not studied. Outbreaks of diseases are associated with depressed oxygen levels, predisposing risk factors include also overcrowding and organic pollution (Kirjusina et al., 2007). In fish farms, outbreaks are typically associated with stress, especially, high temperatures and low oxygen levels.

Bacteria are important pathogens for both cultivated and wild fish, and are responsible for serious economic losses. Inglis et al. (2001), reported that some bacteria cause only surface diseases on skin or gill infections, especially flexibacteria, but some inflict systemic disease. The prevalent fish diseases in fish farms are usually initiated by bacteria. Streptococcus spp and Proteus spp among others are important fish pathogenic bacteria, causing bacterial infections and associated economic losses in fish culture worldwide (Akinyemi and Yekeen, 2010).

Fish diseases are responsible for heavy mortalities in fishes. Disease signs may include: erosion of the head (exposing the brain), fins and tail (exposing the backbone); eye damage (bulging eyes, blood spots or eroded eyes); gill erosion/fusion (the fish can't breathe properly); surface blood spots (i.e. haemorrhaging, ulceration, abscesses, 
blisters/boils) and distended abdomen full of a straw-coloured sticky fluid (ascites). Internally, there may be haemorrhaging, a swollen digestive tract full of liquid, indicative of gastroenteritis, a swollen kidney, liver and/or spleen, liquefaction of the internal musculature and/or organs and the presence of tumours and/or granulomas. Vibriosis is a common disease of marine fish worldwide, with the signs appropriately described as that of a haemorrhagic septicaemia, i.e. there is abundant surface (particularly around the base of the fins) and internal (often in the musculature) haemorrhaging and necrosis/liquefaction of the organs (especially the kidneys). With advanced cases of disease, the pathogen is rampant throughout the infected animal according to Austin and Austin (2007).

According to Cabello (2006), the range of fish pathogens is steadily increasing and tropical examples include Piscirickettsia salmonis (salmonids rickettsial septicaemia; a disease which was first reported in Chile), Moritella viscosa (winter ulcer disease; this occurred originally in farmed salmon in Iceland) and Pasteurell askyensis (first isolated from Atlantic salmon in Scotland). Apart from the newcomers, aquatic animals have been subjected to many bacteria (Aeromonas, Chryseobacterium, Flexibacter, Photobacterium, Pseudomonas, Renibacterium, Streptococcus, Staphylococcus and Vibrio), viruses [e.g. infectious salmon anaemia (ISA), viral haemorrhagic septicaemia (VHS), infectious pancreatic necrosis(IPN), infectious haematopoietic necrosis (IHN)] and eukaryotic parasites (including sea lice and flukes)

Boyd et al., (1977) described bacteria as single celled organisms which reproduce by binary fission and occur in various shapes of rod (bacillus), spherical (coccus), comma (vibros) and helical (spirillum). Most bacteria pathogenic to fishes are rodshaped, only a few species of spherical pathogen are known to be pathogenic to fishes and there are no helical forms. Many bacteria pathogenic to fishes are psychrophilic. Only a few species will grow above $35^{\circ} \mathrm{C}$. Most have a maximum growth temperature of $35^{\circ} \mathrm{C}$ or less. Many of the psychrophilic species have an optimum growth temperature of $10^{\circ} \mathrm{C}$ and continual replicate at $4^{\circ} \mathrm{C}$.

Antibiotics are drugs of natural or synthetic origin that have the capacity to kill or to inhibit the growth of micro-organisms. Antibiotics that are sufficiently non-toxic to the host are used as chemotherapeutic agents in the treatment of infectious diseases of humans, animals and plants. They have long been present in the environment and have played a crucial role in the battle between man and microbe. However, Drug choices for the treatment of common infectious diseases are becoming increasingly limited and expensive and, in some cases, unavailable due to the emergence of drug resistance in bacteria and fungi-resistance that is threatening to reverse much medical progress of the past 50 years. Dissemination of resistant microorganisms may occur in both hospitals and communities. It is recognized that a major route of transmission of resistant microorganisms from animals to humans is through the food chain (Akinyemi and Fajana, 2011). This study investigates the sensitivities of some synthetic antibiotics on Streptococcus pneumoniae and Proteus mirabilis responsible for mass mortalities of adult fish in fish tanks at Ikoto, Odogbolu Local Government Area. 


\section{Materials and methods \\ Studyarea}

The study was carried out at Noble Fish

Farms, Ijebu-Ode, Ogun State, Nigeria located on geographical grid on latitude $06^{\circ} 12^{1}$ North and longitude $3^{\circ} 14^{1}$ East (using Geographical Positioning System [GPS] Model-GARMIN GPSMAP 76CSX). Samples collection

Carcasses of catfishes and water samples from fish tanks belonging to Noble Fish Farms, Ijebu-Ode were randomly collected for the study. They were transported to the laboratory in a sterile polythene bag immediately they were collected for bacteriological examination. Water samples were aseptically collected by the use of sterile sampling bottles from ponds where there are cases of fish diseases and examined for presence of microbes.

Gills and skin were collected aseptically using sterile scarpel after the fish carcass has been obtained. Each organ was aseptically collected into a sterile McCarteny bottles, labeled A and B, being gills, and skin respectively.

Water samples were aseptically collected into sterile universal containers and labeled, the water samples were transported to the Laboratory for bacteriological examination, immediately they were collected.

\section{Laboratory analyses of collected samples Isolation of bacteria}

Fish specimen: One gramme $(1 \mathrm{~g})$ of each of the fish specimen was emulsified and thoroughly mixed in $10 \mathrm{ml}$ of sterile distilled water to have stock culture.

Water samples: One milliliter $(1 \mathrm{ml})$ of each of the water sample was thoroughly mixed in $10 \mathrm{ml}$ of sterile distilled water to have stock culture.

\section{Serial dilution}

One milliliter $(1 \mathrm{ml})$ of the stock culture was diluted with $9 \mathrm{ml}$ of sterile water aseptically in a bottle which was then shaken together to make serial dilutions of $10^{-1}, 10^{-2}, 10^{-3}, 10$ ${ }^{4,} 10^{-5}$ and $10^{-6}$. One milliliter $(1 \mathrm{ml})$ of the stock culture was diluted with $9 \mathrm{ml}$ of sterile water aseptically in first bottle with the aid of a sterile pipette to make $10^{-1}$ dilution (WHO, 1989). After this, another $1 \mathrm{ml}$ of the diluents was taken from the $10^{-1}$ dilution bottle to be transferred aseptically into another bottle containing $9 \mathrm{ml}$ of sterile water to obtain $10^{-2}$ dilution of sample. This was repeated to get the $10^{-6}$ dilution.

Pour plating and plate count

Onto already sterilized Petri dishes, $1 \mathrm{ml}$ of $10^{-6}$ dilutions of the sample were pipetted and the plates labeled. Thereafter, sterilized MacConkey Agar was poured onto the samples and swirled gently. The plates were allowed to gel and then incubated overnight at $37^{\circ} \mathrm{C}$ for microbial growth. Plate count was done manually by counting the number of colonies and the result multiplied by the dilution factor.

Purification of bacteria

Different bacterial colonies including Streptococcus spp, Proteus spp Pseudomonas spp, Klebsiella sp, E. coli, Staph aureus, and Bacillus subtilis of the microbial growth were picked with sterile platinum wire loop and streaked on sterile MacConkey agar. These plates were incubated at $37^{\circ} \mathrm{C}$ for 24 hours for microbial growth. Distinct colonies were reinoculated on to fresh sterile Nutrient agar by streaking until pure isolates were obtained for characterization and identification.

\section{Characterization of the isolates}

Bacterial isolates were characterized by standard microbiological methods including colonial (size, shape, colour, consistency, edges, elevation and opacity), morphological (Gram staining and arrangement/shape) and biochemical characterization (oxidase, indole, urease, 
citrate, catalase, sugar fermentation, methyl-red and Vorges-proskauer). The results of the various microbiological tests were read and interpreted as described by Bergey (1984)

Identification of Streptococcus pnemoniae and Proteus mirabilis

Bergey's Manual of Bacteriology was used as a guide to identify bacterial isolates present in the samples examined based on various microbiological characterization carried out. However, Streptococcus pnemoniae and Proteus mirabilis were seen to be constant and predominant bacterial isolates among others and are thus singled out for sensitivity test.

Sensitivity assay of Streptococcus pnemoniae and Proteus mirabilis

Turbidity standard for inoculums preparation

Mc Farland standard provides Laboratory guidance for the standardization of number of bacteria for susceptibility testing or procedures requiring a standardization of the inoculums (Fatema et. al., 2007). To standardize the inoculums density for a susceptibility test using a modified method (Ochei and Kolhatkar, 2008), a $\mathrm{BaSO}_{4}$ turbidity standard equivalent to 0.5 McFarland standards or its optical equivalent should be used. The standard was distributed into the screw cap tubes of the same size and volume as these were used to dilute or grow the bacterial inoculums. The tubes were sealed tightly to prevent loss by evaporation and stored in the dark at room temperature.

Antibiotics activities of synthetic antibiotics on Streptococcus pnemoniae and Proteus mirabilis

The antimicrobial activity of 10 commercially available antibiotics on $S$. pnemoniae and $P$. mirabilis isolated from catfish tank culture system in Ogun State collected during disease outbreaks in fish farm, were compared by growth inhibition by the modified disk-agar diffusion method on Nutrient Agar as recommended by Stukus (1997). The following commercial disks of antimicrobial substances used were: Amoxycillin $(25 \mu \mathrm{g})$; Gentamicin (10 $\mu \mathrm{g})$; Nitrofurantoin $(300 \mu \mathrm{g})$; Augmentin $(30 \mu \mathrm{g})$, Tetracycline $(30 \mu \mathrm{g})$ Naladoxic acid $(30 \mu \mathrm{g})$, Cotrimoxazole $(10 \mu \mathrm{g})$, Erythromycine $(30 \mu \mathrm{g})$ Cloxacillin $(30 \mu \mathrm{g})$ and Ofloxacin $(5 \mu \mathrm{g})$ for the synthetic antimicrobial activities

Determination of antimicrobial activity of commercial antibiotics

The commercially available antibiotic discs were placed aseptically with the use of a forceps gently at the centre of Nutrient agar plates that have already been seeded by flooding with the test organisms. The plates were then incubated at $37^{\circ} \mathrm{C}$ for 24 hours. This was done in triplicate. Interpretation of the isolates as sensitive or resistance was based on zones of inhibition using a meter rule in accordance to the standard. The mean values were taken in millimeters (mm)

Datapresentation

Various observed data of the inhibition were presented in tables and percentages to determine the differences between mean inhibition diameters.

\section{Results}

Morphological and biochemical characterization of bacterial isolates

The morphological and biochemical characterization of bacterial isolates from the fish and water samples is shown in Table 1. The total viable counts of bacterial isolates present in the fish and the tank water examined are summarized in Table 2. Sensitivity of Streptococcus pnemoniae and Proteus mirabilis to synthetic antibiotics Inhibition zones of ten (10) commercially 
Idowu, Ikenweiwe, Alimi and Akinyemi

Table 1: Morphological and biochemical characterization of bacterial isolates

\begin{tabular}{|c|c|c|c|c|c|c|c|}
\hline Isolate number & 1 & 2 & 3 & 4 & 5 & 6 & 7 \\
\hline Gram reaction & - & - & - & + & & + & - \\
\hline Shape & Rod & Rod & Rod & Cocci & Rod & Rod & Cocci \\
\hline \multicolumn{8}{|l|}{$\begin{array}{l}\text { Biochemical } \\
\text { characterization }\end{array}$} \\
\hline Catalase & + & + & + & + & + & + & - \\
\hline Coagulase & - & - & - & + & - & - & - \\
\hline Motility & + & - & + & - & + & - & - \\
\hline Indole & - & - & + & - & - & - & - \\
\hline Oxidase & + & - & - & - & - & - & - \\
\hline Citrate & + & + & - & - & - & + & - \\
\hline Urease & - & + & - & - & - & + & - \\
\hline Hydrogen & - & - & - & - & - & + & - \\
\hline \multicolumn{8}{|l|}{ Sulphide } \\
\hline Production & & & & & & & \\
\hline Methyl-red & + & - & + & - & + & + & + \\
\hline Voges proskeur & - & + & - & + & - & - & - \\
\hline $\begin{array}{l}\text { Glucose } \\
\text { assimilation }\end{array}$ & + & + & + & + & + & + & + \\
\hline $\begin{array}{l}\text { Lactose } \\
\text { assimilation }\end{array}$ & - & + & + & + & - & - & - \\
\hline $\begin{array}{l}\text { Sucrose } \\
\text { assimilation }\end{array}$ & - & A & - & - & - & A & A \\
\hline Mannitol & - & A & - & A & - & A & - \\
\hline $\begin{array}{l}\text { Organism } \\
\text { suspected }\end{array}$ & $\begin{array}{l}\text { Pseudomonas } \\
\mathrm{sp}\end{array}$ & $\begin{array}{l}\text { Klebsiella } \\
\mathrm{sp}\end{array}$ & $\begin{array}{l}\text { E. } \\
\text { coli }\end{array}$ & $\begin{array}{l}\text { Staph } \\
\text { aureus }\end{array}$ & $\begin{array}{l}\text { Bacillus } \\
\text { subtilis }\end{array}$ & $\begin{array}{l}\text { Proteus } \\
\text { mirabilis }\end{array}$ & $\begin{array}{l}\text { Streptococcus } \\
\text { pneumonia }\end{array}$ \\
\hline
\end{tabular}

produced synthetic antibiotic discs on $S$. This was followed by Gentamycin with pnemoniae and P. mirabilis is presented in mean inhibition diameter of $24 \mathrm{~mm}$ Table 3. Ofloxacin had the highest (24.4\%), $19 \mathrm{~mm}(23.2 \%)$ and $15 \mathrm{~mm}$ inhibition zone of mean inhibition diameter $\quad(30.6 \%)$ around Streptococcus and Proteus of $26 \mathrm{~mm}(26.5 \%), 20 \mathrm{~mm}(25.6 \%)$ around respectively. However, Naladoxic acid, Streptococcu $s p$ and Proteus respectively. Augmentin, Cloxacillin and Amoxycillin

Table 2: Total viable counts of bacterial isolates in fish and tank water

\begin{tabular}{|c|c|c|}
\hline Sample & $\begin{array}{l}\text { Total viable count } \\
\left(\mathrm{X} 10^{6} \mathrm{CFU} / \mathrm{G}\right)\end{array}$ & Organism \\
\hline Skin & 8.6 & $\begin{array}{l}\text { Pseudomonas sp., Proteus } \\
\text { mirabilis, Streptococcus } \\
\text { pneumonia, Bacillus } \\
\text { subtilis }\end{array}$ \\
\hline Gill & 6.5 & $\begin{array}{l}\text { Staphylococcus aureus, } \\
\text { Proteus mirabilis, } \\
\text { Streptococus pneumonia }\end{array}$ \\
\hline Tank A & 9.6 & $\begin{array}{l}\text { Klebsiella sp., Proteus } \\
\text { mirabilis, Streptococcus } \\
\text { pneumonia } \\
\text {.E.coli,Pseudomonas sp. }\end{array}$ \\
\hline Tank B & 7.3 & $\begin{array}{l}\text { E.coli., Streptococcus } \\
\text { pneumonia, Proteus } \\
\text { mirabilis }\end{array}$ \\
\hline
\end{tabular}


Efficacy synthetic antibiotics on Streptococcus pneumoniae and Proteus mirabilis isolated from fish tanks

Table 3: Inhibition zones of nine (9) commercially produced synthetic antibiotics discs on $S$. pnemoniae and P. mirabilis

\begin{tabular}{|c|c|c|c|c|c|}
\hline \multirow{3}{*}{ Antibiotics } & \multicolumn{5}{|c|}{ Mean inhibition zones $(\mathrm{mm})$} \\
\hline & S. pnemoniae & & \multirow[b]{2}{*}{ Perc. $(\%)$} & \multirow[b]{2}{*}{ P. mirabilis } & \\
\hline & & & & & Perc. (\%) \\
\hline Ofloxacine & $26(\mathrm{~S})$ & & 26.5 & $20(\mathrm{~S})$ & 25.6 \\
\hline Gentamycin & $24(\mathrm{~S})$ & & 24.4 & $19(\mathrm{~S})$ & 24.4 \\
\hline Erythromycine & $16(\mathrm{~S})$ & & 16.3 & $17(\mathrm{~S})$ & 21.8 \\
\hline Cotrimoxazole & $10(\mathrm{R})$ & & 10.2 & $13(\mathrm{R})$ & 16.7 \\
\hline Tetracycline & $12(\mathrm{R})$ & & 12.2 & $10(\mathrm{R})$ & 12.8 \\
\hline Nitrofurantoin & $10(\mathrm{R})$ & & 10.2 & $9(\mathrm{R})$ & 11.5 \\
\hline Cloxacillin & 0 & & 0 & $0(\mathrm{R})$ & 0 \\
\hline Augumentin & $00((\mathbb{R}))$ & 0 & $0 ®$ & $0(\mathrm{R})$ & 0 \\
\hline Amoxycillin & $0(\mathrm{R})$ & & 0 & $0(\mathrm{R})$ & 0 \\
\hline Naladoxic acid & $0(\mathrm{R})$ & & 0 & $0(\mathrm{R})$ & 0 \\
\hline Total & 98 & & 100 & 78 & 100 \\
\hline
\end{tabular}

exhibited no zone of inhibition (0mm) around test organisms.

\section{Discussion}

The result derived from the characterization shows that there are Gram negative bacilli and Gram positive cocci. All the isolates were positive to Catalase test except Streptococus pneumonia and also, all were negative to Hydrogen sulphide production except Proteus mirabilis. However, Streptococus pneumonia and Proteus mirabilis vary in reactions to other tests. The biochemical test as described by Ochei and Kohaltkar (2008) indicated that Streptococus pneumoniae is cocci in shape and arrangement and reacted positive to Gram reaction and methyl red tests but negative to other tests, produced acid in sugar fermentation test using glucose, sucrose but not in lactose sugar and manitol. Whereas P. mirabilis was observed to be rod like and reacted positive to citrate, urease, $\mathrm{H}_{2} \mathrm{~S}$ production, methyl red and catalase tests, but negative to Gram reaction, coagulase, motility, indole and oxidase tests. The organism also produced acid in sugar fermentation test using glucose and sucrose sugars and manitol but not in lactose sugar. These results were confirmed by Bergey, 1984.

Effect of synthetic antibiotics on the fish pathogenic bacteria under laboratory condition provided useful information for treatment of bacterial fish diseases. Also, the emergence of multi-drug resistance in human and animal pathogenic bacteria including fish pathogens as well as undesirable side effects of certain antibiotics has triggered immense interest in the search for more potent antimicrobial drugs. Proteus mirabilis and Streptococcus pneumonia among others were observed to be constant and predominant in all the samples examined. Therefore, they were suspected to be responsible for the mortalities in the culture media. Thus, Proteus mirabilis and Streptococcus pneumonia were singled out for sensitivity test. Other isolates including Pseudomonas spp, Klebsiella spp, E. coli, S.aureus and Bacillus subtilis were present as opportunistic microbes and are considered of little or no interest to this study. Antibiotic sensitivity and resistance tests of Proteus mirabilis and Streptococcus pneumonia was performed under in-vitro 
condition to determine inhibitory efficacy of various antibiotics tested. Ofloxacin had the highest inhibition zones around the test organisms with average inhibition diameter of $26 \mathrm{~mm}(26.5 \%)$ and $20 \mathrm{~mm}(25.6 \%)$ on $S$. pnemoniae and $P$. mirabilis respectively. This was followed by Gentamicin with average inhibition diameter of $24 \mathrm{~mm}$ (24.4\%), and $19 \mathrm{~mm}(24.4 \%)$ on $S$. pnemoniae and $P$. mirabilis respectively. Erythromycin was next with zone of inhibition $16 \mathrm{~mm}(16.3 \%)$ and $17 \mathrm{~mm}$ (21.8\%) on S. pnemoniae and P. mirabilis respectively. However, Cloxacillin, Augmentin, Amoxycillin and Naladoxic acid had no inhibition $(0 \mathrm{~mm})$ around the two organisms tested. Although Cotrimoxazole, Tetracycline and Nitrofurantoin had inhibition zones around the test organisms, but they are considered to be resisted by these organisms because the antibiotics inhibition zones around them were less than $14 \mathrm{~mm}$ (CLSI, 2007).

The sensitivity of some organism like Pseudomonas aeroginosa, and Aeromonas sobria, among others which reacted negative to Gram reaction, positive to Catalase and Citrate tests to drugs like Ofloxacin and Gentamycin and resistant to drugs like Cloxacillin, Amyxocillin and Naladoxic acid had been reported by Akinyemi, (2012). Proteus mirabilis and Streptococcus pneumonia were discovered to show similar sensitivity to drugs mentioned above in this work.

\section{Conclusion and Recommendation}

This study provided information on the bacteria (S. pnemoniae and P. mirabilis) sensitivity to

(10) Synthetic antibiotics (Tetracycline, Erythromycine, Cotrimoxazole, Gentamycin, Naladoxic acid Nitrofurantoin, Augmentin Ofloxacin and Cloxacillin). This study confirms the potency of Ofloxacin, Gentamicin and Erythromycin because they showed highest inhibition zones among the synthetic antibiotics used. Thus, the three drugs can be effectively used in combating Streptococcus pnemoniae and Proteus mirabilis infections in fish.

\section{References}

Akinyemi, A. A. 2012. Plant extracts as alternative treatment for Pseudomonas aeruginosa occurrence in Clarias gariepinus (Burchell, 1822) juveniles. Journal of Science and Multidisciplinary Research Volume 4, Cenresin Publications

Akinyemi, A. A. and Yekeen, O. A. 2010. Occurrence of bacteria found in gills, skin and buccal cavity of Psettiae sebae (Cuvier 1829), Pomadasys jubelini (Cuvier, 1830) and Cynoglosus senegalensis (Kaup, 1858) from Lagos Lagoon, Nigeria. Journal of Agriculture and Veterinary Sciences 2: 81 - 89 URL: www.cenresin.org Published by Centre for Research and Innovations, Nigeria

Akinyemi, A. A. and Fajana, O. P. 2011. Antibiotics sensitivity and occurrance of bacteria originated from skin, gill and buccal cavity of Chrysicthys nigrodigitatus, Distichodus engycephalus and Synodontis schall sampled in Arakanga reservoir, Abeokuta, Ogun state, Nigeria. Journal of FisheriesSciences.com 5-(2): $164-171$. D O I : $10.3153 /$ jfscom.2011020 URL: www.fisheriessciences.com

Austin, B. and Austin, D.A. 2007. Bacterial Fish Pathogens: Disease of Farmed and Wild Fish. Praxis Publishing 
Efficacy synthetic antibiotics on Streptococcus pneumoniae and Proteus mirabilis isolated from fish tanks

Boyd, D., Peters, G.A., Cloeckaert, A., Boumedine, K.S., Chaslus-Dancla, E., Imberechts, H. and Mulvey, M.R. 2001. Complete nucleotide sequence of a 43-kilobase genomic island associated with the multidrug resistance region of Salmonella enterica serovar Typhimurium DT104 and its identification in phage type DT120 and serovar. Agona. J. Bacteriol. 183: 5725-5732.

Bergey, D. H. 1985. Bergey's Manual of Systematic Bacteriology Book Review Int. J. of Syst. Bact., pp. 408

Cabello, F. C. 2006. Heavy use of prophylactic antibiotics in aquaculture: a growing problem for human and animal health and for the environment. Environmental Microbiology 8: 1137-1144.

Clinical and Laboratory Standards Institute (CLSI) 2007. Performance standard for antimicrobial susceptibility testing: Seventeenth informational supplement. Vol 27, No. 1

Fatema, H., Eisin, S., Friona, B., Pamela, C. Mohamad, R. T. Allan, J. D. Alexandra, I. G. and Valerie, A. F. 2007. Screening methods used to determine the antimicrobial properties of Aloe vera inner gel. Nat. Prod. Res. 42 (4): 315-320.
Inglis, V., Roberts, R.J. and Bromage, N.R. 2001. Bacterial Diseases of Fish. Iowa State University, Ames. pp. 1 $-59,122-156$.

Jay, J.M. 1986. Modern food microbiology, Van Nostrand Reinhold New York, pp. 27

Kirjusina, M., Briede, I. and BondadReantaso M.G. 2007. Extension Manual on Some Important Viruses, Parasites and Bacteria of Aquatic Animals in Lativia. NDC/LZRA/FAO. Riga. 69 pp.

Ochei, J. and Kohaltkar, A. 2008. Medical Laboratory Science, Theory and Practice. Tata McGraw-Hill Publishing Company Limited, New Delhi.

Stukus, P.E. 1997. Antimicobial testing. The Kirby-Bauer method (filterpaper disk method). In: Stukus, P.E. (Ed.). Investigating microbiology: a laboratory manual for general microbiology. Orlando: Harcourt Brace \& Company cap.44, p.243-247.

World Health Organization (WHO) .1989. Tropical disease: Progress in International Research 1987-1988. $9^{\text {th }}$ edition pp 55-62

Received: $15^{\text {th }}$ December, 2013 Accepted: $28^{\text {th }}$ May, 2014 